\title{
Review on Rice Improvement for Drought Tolerance
}

\author{
Dejen Bekis* \\ Ethiopia Institute of Agricultural Research, Fogera National Rice Research and Training Center, South \\ Gondar, Ethiopia
}

*Corresponding Author: Dejen Bekis, Ethiopia Institute of Agricultural Research, Fogera National Rice Research and Training Center, South Gondar, Ethiopia

\begin{abstract}
Rice is one of the most consumed staple food crop and assists as a chief food basis for more than half of the world population. The objective of this paper was to review recent efforts achieved in rice breeding for drought tolerance. Most of the world's rice is cultivated and consumed in Asia. Although Asia is the main place of rice cultivation; it also harvested in other continents like Latin America, Europe, USA and some parts of Africa. Rice was introduced in to Ethiopia during the 1970s and fast distribution of the crop within the country has been achieved due to the presence of vast suitable agro ecologies for rice production. However, production of rice was decreasing through time due to many biotic and abiotic stresses. Among them drought is one of the most serious and common abiotic stress which affect yield and other traits of rice. Early, intermittent or continuous and late drought stresses are three basic drought patterns affecting rice production. Drought in rice has a big impact both in economic and morphological characteristics of rice. Rice, like other crops, can potentially resist drought stress using three different strategies, such as drought escape through short duration varieties, avoidance and using drought tolerance traits. Conventional breeding, marker-assisted selection and genetic engineering are the main breeding approaches to develop drought tolerance rice varieties. Modern breeding approaches have a greater advantage than conventional for drought tolerance that can be identify a desirable gene, even in the absence of a visible trait, more precise and efficient and identify undesirable genes that can be eliminated in future generations. Among molecular markers, RAPD and ISSRs have become excellent tools for rice breeders. Ethiopia has wide agricultural drought prone environments. However, not yet identify rice genotypes for drought tolerance. So, it needs a great effort to develop drought tolerant high yielding rice varieties in the country.
\end{abstract}

Keywords: Conventional breeding, Drought tolerance, Genetic engineering, Marker-assisted selection, Rice

\section{INTRODUCTION}

Rice ( Oryza sativa L. and Oryza glaberrima Steud) belongs to the family Poaceae, is the most consumed staple food crops of the world and assists as a chief food basis for more than half of the world population(Wang et al., 2014). Rice is the second most-produced cereal in the world after wheat (Luz et al., 2016). Historically, rice was cultivated 10000 years ago in the river valleys of South and Southeast Asia and China. Most of the world's rice is cultivated and consumed in Asia (Chakravarthi and Naravaneni, 2006). Although Asia is the main place of rice cultivation; it also harvested in other continents like Latin America, Europe, USA and some parts of Africa (Zibaee, 2013).

Rice was introduced in to Ethiopia during the 1970s and fast distribution of the crop within the country has been achieved due to the presence of vast suitable agro ecologies for rice production (Beakal et al, 2016). Rice has been recognized by the government as "the new millennium crop of Ethiopia" to attain food security (MOARD, 2010). Rice research has been started at different regional and EIAR centers with full collaboration of Fogera National Rice Research and Training Center (FNRRTC).

Based on International Rice Research Institute (IRRI) classification, rice is cultivated through four production ecosystems (irrigated, lowland, upland and flood-prone) (Calpe, 2006). However, production of rice was decreasing through time due to many biotic and abiotic stresses. Among them drought is one of the most serous and common abiotic stress which affect yield and other traits of rice. Taking the world's total land surface area, hyper-arid zones represent $4.2 \%$; arid zones represent $14.6 \%$ and semi-arid zones $12.2 \%$. Thus, close to one-third of the world's total land surface 
area is made up of arid land. Beside agricultural drought is caused by insufficient quantities of water in the superficial ground store during the growing season. Worldwide, drought affects approximately 23 million ha of rain fed rice. Drought is particularly frequent in unbunded uplands and bunded uplands fields in many parts of South and Southeast Asia, Sub Saharan Africa, and Latin America. It also affects production on millions of hectares in water-short irrigated areas dependent on surface irrigation, where, in drought years, river flows and water in ponds and reservoirs may be insufficient to supply the crop. Thus, drought vulnerability scenarios are likely to worsen in the future with predicted climate change scenarios (Wassmann et al., 2009).

There are several ways of overcoming drought. Hence, review paper attempt to clarify those solutions, which was gained through rice breeding program. Objective is therefore, to review recent efforts achieved in rice breeding for drought tolerance beside for rice production improvement in the country in one way or another accordingly.

\section{IMPORTANCE OF RICE}

Rice is a major source of energy and protein: 100 grams of raw white rice provide $361 \mathrm{kcal}$ and 6 grams of protein. Rice also contains substantial amounts of zinc and niacin (Calpe, 2006). Rice provides $21 \%$ of energy and $15 \%$ of protein for human (Zibaee, 2013). The non-food rice parts also used for different purposes such as: a fuel, paper manufacturing, packing and building materials, compost preparation and animal feed (ABSF, 2010).

World rice production is spread across at least 114 countries (FAO, 2013) and rice is grown on 144 million farms worldwide more than for any other crop. In Asia, it provides livelihoods not only for the millions of small-scale farmers and their families but also for the many landless workers who derive income from working on these farms (Mohanty, 2013).

In addition, rice plays an important cultural role in many countries. Growing, selling and eating rice is integral to the culture of many countries. Many traditional procedures surrounded in the preparation of the rice beds, sowing and harvest of the crop. China's rural culture has developed around the growing of rice and foods made from rice are the basis of festivals such as the land opening festival, which marks the start of the rice cultivation season, and the spring festival. Even in western countries, rice is an important culture (http:// www. Nodai.ac.jp/cip/iss/, 2015).

\section{TyPES OF DROUGHT IN RICE}

Drought is defined in a number of ways reflecting various perspectives and interests. The three commonly used definitions are meteorological, hydrological and agricultural drought. Drought is inadequacy of water availability, including precipitation and soil moisture storage capacity, in quantity and distribution during the life cycle of plants. It is not simply the lack of water that lowers yield potential, but also the timing and duration of drought stress related to phenological processes (Jongdee et al., 2006). There are three basic drought patterns affecting rice production:

* Early drought: It occurs during vegetative growth, after establishment but before maximum tillering. Early droughts often result in delayed sowing or transplanting. Yield reductions from early droughts are often minimal and result mainly from a reduction in tiller numbers.

* Intermittent or continuous droughts: Occurs between the tillering and flowering stages, may greatly reduce yields despite no apparent drought symptoms, mainly as a result of reduced leaf expansion and photosynthesis.

* Late (occurring after panicle initiation) drought stresses: When drought occurs during later growing stages, especially during flowering, reduced spikelet fertility is the main factor contributing to yield loss. Since the diverse drought patterns have different impacts on the crop, it is important to define which type of drought stress is targeted by a breeding program (Liu et al., 2006)).

\section{IMPACTS OF DROUGHT IN RICE}

\subsection{Economic Impacts of Drought Stress on Rice Production}

The annual global reduction of rice production due to drought averaged 18 million tons. In Asia alone, it is estimated that a total of 23 million ha of rice fields (10 million ha in upland and 13 
million ha in lowland) are drought-prone. In eastern India, more than 10 million ha of drought-prone upland and lowland fields, where yield losses due to drought are reported to cost an average of US \$250 million annually (Pandey et al., 2000).

Drought affects the poorest farmers disproportionately, causing them to reduce their food consumption, withdraw their children from school and migrate for employment to meet immediate needs. Farmers growing rice in drought-prone environments are well aware of the risks involved and are consequently very reluctant to use expensive agricultural inputs such as fertilizers; this further reduces yield potential of rice (Courtois et al, 2000).

\subsection{Effects of Drought Stress on Morphological Characteristics of Rice}

Responses to drought stress are commonly dependent on plant species, genotypes, age of plant, developmental stage and severity of drought (Gall et al., 2015). Water use efficiency varies particularly due to variation of species and climate during drought stress period (table 1).

Table1. Total water requirements of some plants (rainfall and irrigation)

\begin{tabular}{|l|c|}
\hline Plant & Water uptake (L/kg DNM) \\
\hline Maize* & 238 \\
\hline Banana & 346 \\
\hline Maize (grain)* & 454 \\
\hline Barley* & 524 \\
\hline Potato* & 590 \\
\hline Wheat* & 590 \\
\hline Soybean & 900 \\
\hline Upland Rice & 1600 \\
\hline Floded Rice & 5000 \\
\hline
\end{tabular}

Source: (Laure et al., 2010)

Drought stress is characterized by:

* Reduction of water content, diminished leaf water potential,

* Turgor loss, closure of stomata and decrease in cell enlargement and growth (Fig. 1)

- Severe drought stress may result in the arrest of photosynthesis, disturbance of metabolism a nd finally the death of plant (Jaleel et al., 2009).

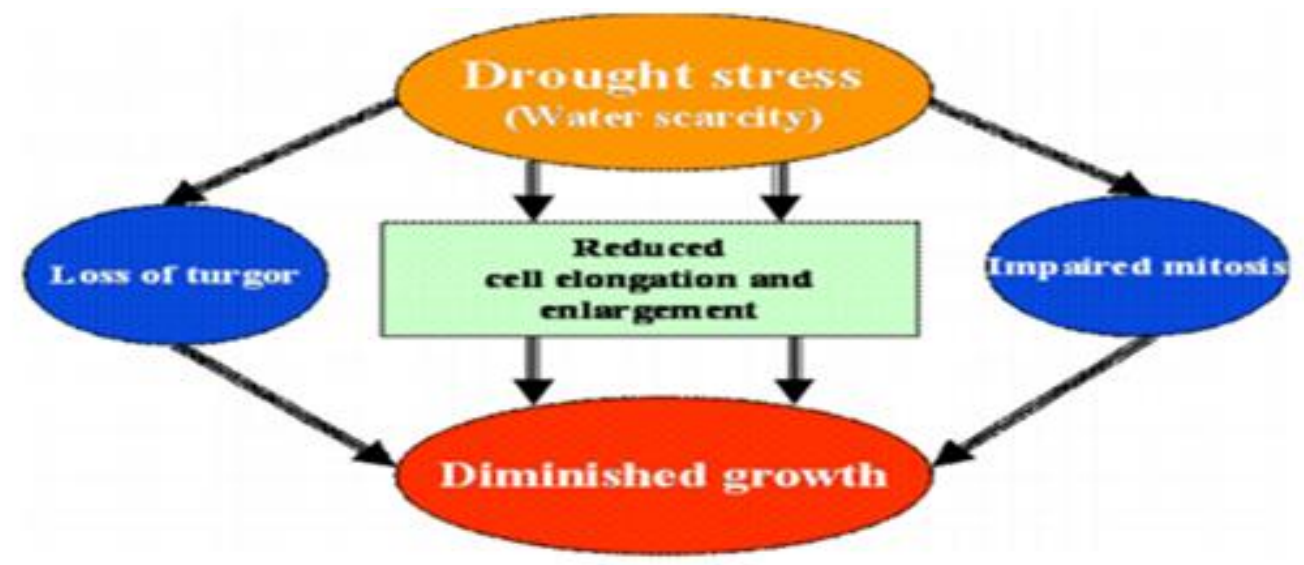

Fig1. Some important causes of growth reduction in plants under drought stress

Source: (Jaleel et al., 2009)

Drought stress is a very important limiting factor at the initial phase of plant growth and establishment. It affects both elongation and expansion growth (Shao et al., 2008). Rice as a submerged crop is probably more susceptible to drought stress than most other plant species (Fig. 2).

The reduction in plant height was associated with a decline in the cell enlargement and more leaf senescence. Development of optimal leaf area is important to photosynthesis and dry matter yield. A common adverse effect of drought stress in rice is the reduction in fresh and dry biomass production. Rice productivity under drought stress is strongly related to the processes of dry matter partitioning and temporal biomass distribution (Kage et al., 2004). The partitioning of dry 
matter to the head is critical in the process of yield determination in water stressed condition. The yield components like grain number and grain size were commonly decreased under preanthesis drought stress in rice (Petropoulos et al,

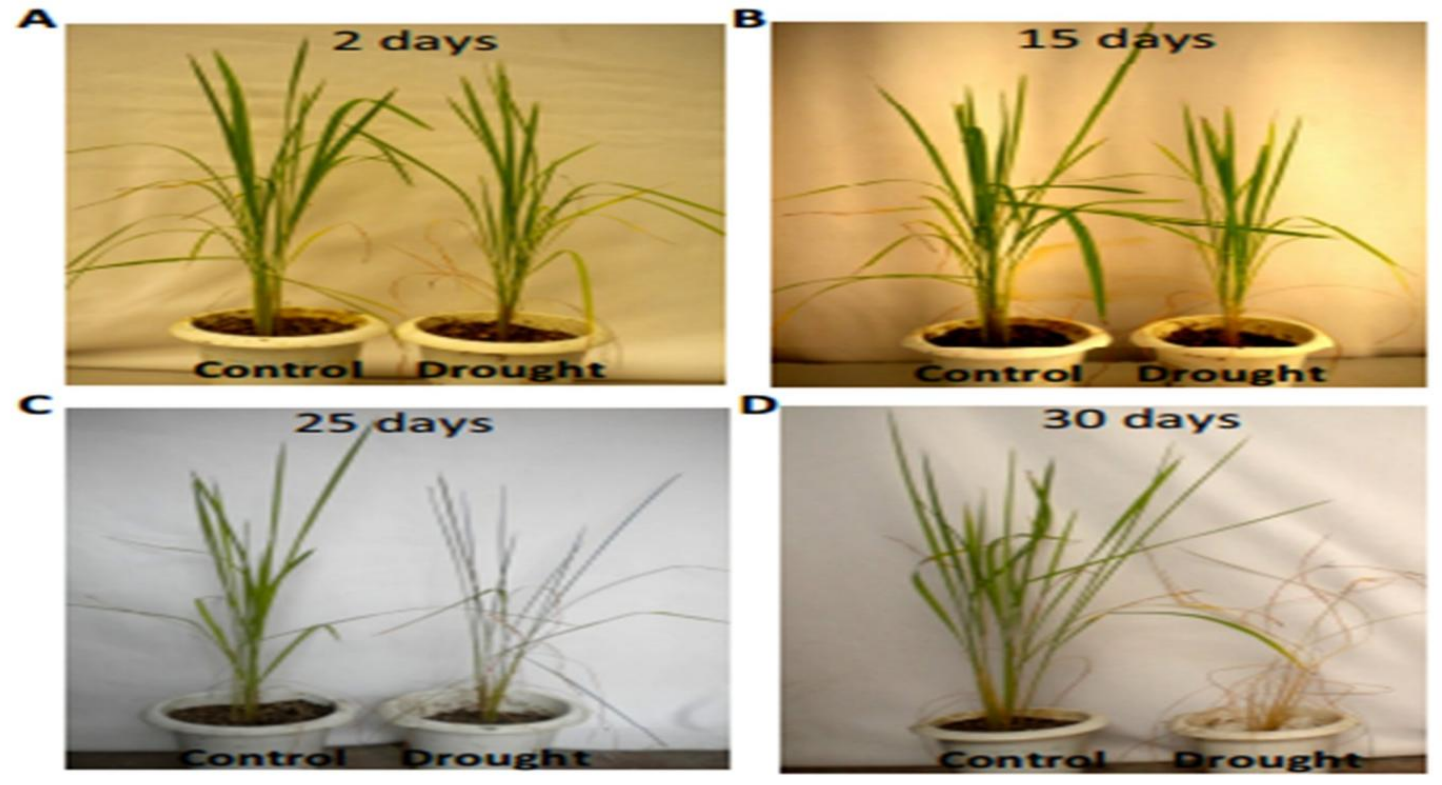

Fig2. Response of rice plants for prolonged drought stress

Source: (Khirod et al., 2013)

Note: Leaf rolling started to appear within 15 days (B) of water withdrawal which eventually causes complete wilting and bleaching of chlorophyll upon prolonged drought stress30 days (D) leading to the death of the plant.

\section{MEChANiSM OF DROUGHT TOLERANCE}

Drought tolerance implies the ability of plants to grow with subsequent satisfactory yield under drought conditions. Rice is a notoriously drought-susceptible crop due in part to its shallow root system, rapid stomatal closure and leaf senescence during mild water stress. Rice, like other crops, can potentially resist drought stress using three different strategies (Hirasawa, 1999).

\subsection{Drought Escape Through Short Duration Varieties}

A proper timing of the life cycle, resulting in completion of the most sensitive developmental stages while water is abundant, is considered to be a drought escape strategy. In drought-prone upland areas, drought escape is an important mechanism that allows rice to produce grain despite limited water availability. Short-duration varieties of the aus germplasm group are commonly used in upland fields. Some of which can reach maturity as little as 80 days (Khush, 1997). Shortduration varieties also occur within the tropical japonica germplasm group; these varieties are particularly important in rice producing areas in West Africa and include drought avoidant varieties such as WAB56-140, which was used as a recurrent parent to produce some NERICA varieties ( Ndjiondjop, 2006).

\subsection{Drought Avoidance}

Drought resistance mechanisms can be expressed even in the absence of stress such as deep rooting and stomatal control considered as drought avoidance mechanisms.

\subsubsection{Drought Avoidance Through Deeper Root Distribution}

It is clear that the root system of rice is very poorly adapted to water-limited conditions. Rice can extract water from the top $60 \mathrm{~cm}$ of soil. Production of ramified root system under drought is important to above ground dry mass and varieties of a species show great differences in the production of roots (Fig. 3). A deeper root system has been shown to allow upland rice to extract more water from the soil, resulting in a higher yield potential under drought and varieties with high deep-root weight to shoot weight ratio exhibit enhanced drought resistance in upland rice (Farooq et al., 2009). 
In addition to the drought avoidance benefits associated with the improved access to water with deeper roots, there is strong evidence from other species that a reduction of root density in fastdrying upper soil levels has resulted in reduced drought sensitivity. It is likely that a reduction in root biomass near the soil surface reduces root signals associated with intermittent soil drying, reducing premature stomatal closure and reduced transpiration in response to mild stress (Yambao et al., 1999).
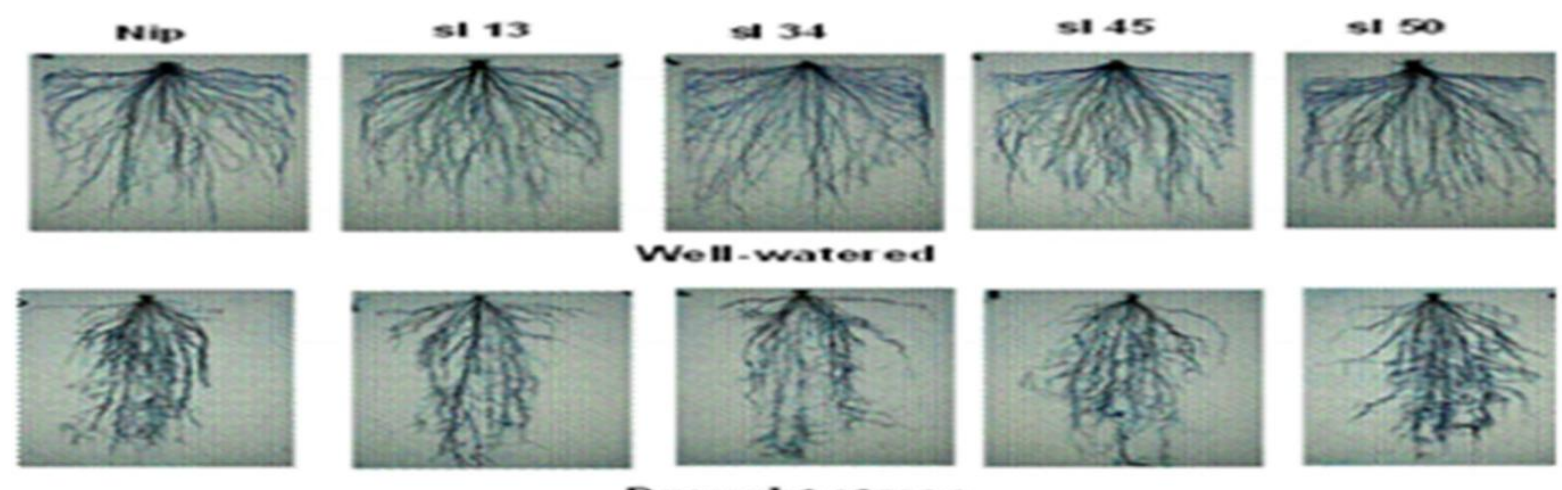

Fig3. Root growth and proliferation under well-watered and drought stress conditions in various rice genotypes

Source: (Farooq et al., 2009)

\subsubsection{Drought Avoidance Through Stomatal Control}

Early stomatal closure is very essential at the beginning of a period of water deficit. Stomatal closure reduces: Water loss, gas exchange between the plant and the ambient air and $\mathrm{CO} 2$ intake then results in reduced photosynthesis (Medrano et al., 2002). Early stomatal closure may be desirable under some circumstances, but not where droughts are short, frequent, and relatively mild. Regulation of stomatal conductance is very complex and poorly understood, but thought to be mainly a consequence of leaf cell response to water deficit and to a lesser extent, a consequence of low root water status communicated to the leaf via abscisic acid (ABA) signaling. Significant genetic variation for the sensitivity of stomata to leaf water status has been reported in rice (Medrano et al., 2002).

\subsection{Drought Tolerance Traits}

Drought tolerance mechanisms are triggered by drought stress itself and considered as adaptive.

\subsubsection{Stability of Flowering Processes}

Drought stress at the beginning of the reproductive stage usually results in a delay in flowering for rice. This is mainly due to slowed elongation of the panicle and supporting tissues. This trait can be an effective drought avoidance mechanism if the period of water deficit is short, as panicle elongation resumes following a brief period of stress. However, if flowering is delayed by more than a few days, severe yield losses usually occur (Lafitte et al., 2004).

It has been reported that the greater the delay in flowering, the greater the yield and harvest index reduction due to drought. Improving drought resistance may therefore involve selection of plants exhibiting little or no flowering delay due to drought (Pantuwan et al., 2002). There is considerable genetic variation for flowering delay under stress; some short-duration varieties actually exhibit accelerated flowering under drought stress (Bernier et al., 2007).

\subsubsection{Partitioning and Stem Reserve Mobilization}

As photosynthesis becomes inhibited by drought, the grain-filling process becomes increasingly reliant on stem reserve utilization. This drought tolerance mechanism is stimulated by a decrease in gibberellic acid concentration and an increase in abscisic acid concentration in grains. Numerous studies have reported that stem reserve mobilization capacity is related to yield under water stress in wheat. In rice, a few studies also suggest that this mechanism maintains grain yield under water stress at the grain-filling stage (Bernier et al., 2007). 
Generally, rice varieties possessing drought avoidance and tolerance mechanisms are required in situations when the timing of drought is mostly unpredictable. When stress is predictable and terminal, varieties that can escape drought by maturing early may be the most appropriate choice for rice producers (Pantuwan, 2002).

\section{RICE BREEDING APPROACHES FOR DROUGHT TOLERANCE}

\subsection{Prerequisite to Develop Drought Tolerant Varieties}

Existence of genetic variability for drought tolerance within species is of paramount importance in crop improvement program. Therefore, selection of germplasm and developing methodologies for the success of breeding program is most critical steps.

\subsubsection{Defining Target Population of Environments (TPE)}

Target population of environments (TPE) is the set of all environments, fields and season in which an improved variety is targeted to perform well. The first approach requires historical weather data while the second requires reference genotypes, which are known for their adaptation to each target environment. In some cases where environmental information may not be available, information can be directly obtained from farmers (Mackill et al., 1996).

\subsubsection{Developing Methods to Select for Drought Tolerance}

There was growing evidence that varieties can be developed for improved yield under drought stress and respond well to favorably-watered conditions (i.e. the good years) if there is early selection for yield under both drought and well-watered conditions. Plant breeders rely on direct selection for grain yield as the main criterion for selection. The process might be more efficient by the use of indirect traits associated with drought (Fukai and Cooper, 2001).

\subsubsection{Development of Drought Screening Facilities}

Facilities for field screening for drought resistance at the vegetative and reproductive stages should be developed at three stations. This strategy is particularly useful to evaluate larger number of genotypes for drought score in the dry season and selected ones can be evaluated for grain yield in the wet season (Sarkarung and Pantuwan, 1999).

\subsubsection{Selection of Parental Materials for Drought Tolerance}

Breeders often used parents from exotic materials to improve grain yield and phenology, while local materials for maintenance or enhancement of drought tolerance. Sources of drought resistance genes: cultivated varieties, wild relatives, landraces and tansgenes. Currently, a large effort is under way to identify putative drought tolerant lines to be used further in the breeding program (Table1 and Fig2, 3, 4).

\subsection{Conventional Breeding Approach}

Conventional breeding methods commonly followed the development of the drought tolerant materials through introduction, selection, hybridization, mutation and shuttle breeding approaches. Conventional breeding requires the identification of genetic variability to drought among crop varieties or sexually compatible species. Farmers in drought-prone regions often favor traditional cultivars that require limited inputs in order to cope with the uncertainty of water supply (Cooper et al., 1999).

Progress of developing high-yielding drought-tolerant rice cultivars by conventional breeding has been low, largely due to difficulties in precisely defining the target environment, complex interactions of drought tolerance with environments, limited by the availability of suitable genes for breeding and lack of appropriate screening methodology (Wade et al., 1999).

This may be also explained by the fact that drought resistance is a trait controlled by many genes having different effects and affected by drought timing and severity. Another way to explain the complexity of drought is that drought resistance involves an interaction between the genes involved in yield potential per season(which are numerous) and the genes for drought resistance( Mohan et al., 2002).

Most conventional plant breeders in rain-fed systems use the early screening phase to select for traits such as height, maturity, plant type, tolerance and grain quality under well-watered conditions 
on research stations. Only in the advanced testing stage, a few remaining genotypes were evaluated under the stress conditions of farmers' fields. The outcome is often a variety that performs well under well-watered conditions and poorly under stress (Fischer et al., 2003).

There are three major conventional breeding targets that may improved grain yield under drought stress condition: increasing yield potential per season, timing of flowering when water is available and improving drought resistance. Screening for increased yield potential is generally performed under ideal conditions. Direct selection for yield under favorable or water limited conditions is the most commonly used selection strategy used by breeders to improve yield in water-limited environments (Venuprasad et al., 2007).

Selecting genotypes that complete flowering before the onset of water stress is possible if the timing of drought is predictable and terminal. However, in many areas where upland rice was grown, brief periods of drought stress was occurred particularly around flowering. Selection for drought resistance can be performed by measuring yield under stress conditions and/or measuring a secondary character correlated with yield under stress conditions (Passioura et al., 2006). In upland rice, the application of managed drought stress usually enables clear differentiation between resistant and susceptible lines on the basis of yield only if yields are reduced by at least $70-80 \%$ relative to unstressed levels. Direct selection for yield under managed stress, when combined with concurrent selection for yield potential, is an effective and underutilized approach to developing stress-tolerant upland rice varieties (Venuprasad et al., 2007).

Dry season drought screening results must be interpreted cautiously because off season photoperiod, solar radiation intensity, temperature, evaporative demand, and disease pressures often differ from those characteristic of the wet season. However, there are locations (IRRI) in several South and Southeast Asian countries where dry season conditions are suitable for drought screening (Venuprasad et al., 2007)(Fig.4).
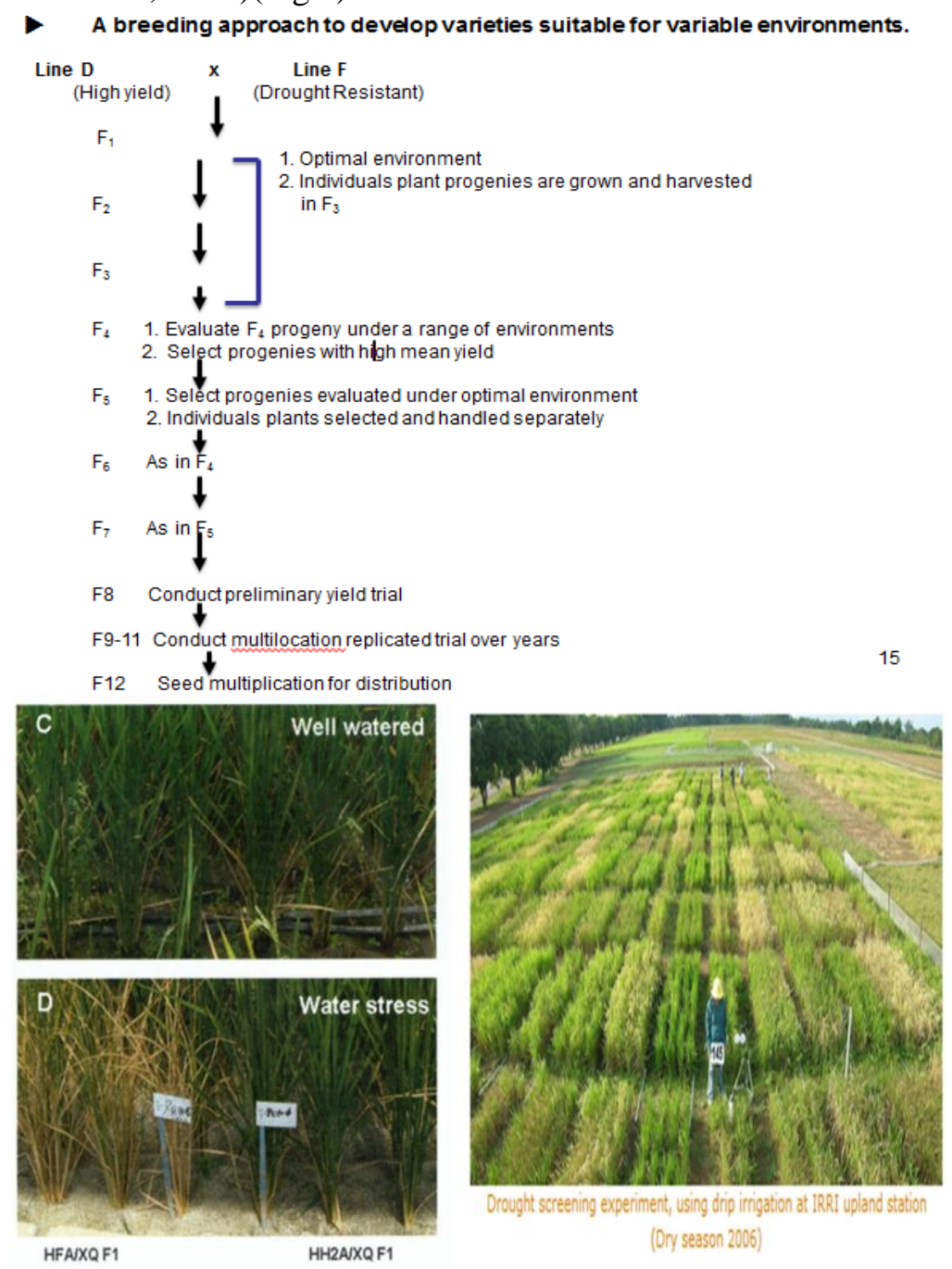

Fig4. The visual field performance of upland rice varieties for drought tolerance at IRRI

Source: (Jerome et al., 2008) 


\subsection{Marker-Assisted Selection (MAS)}

Mapping studies are performed to detect linkage of a molecular marker to a gene affecting a trait of interest. It then becomes possible to select for the desirable allele of those genes based on marker genotype rather than phenotype. This technique, known as marker assisted selection, is theoretically more reliable than selection based solely on phenotype (Jongdee et al., 2002).

As conventional breeding attempts to select simultaneously for more and more target traits, there tends to be an overall loss of breeding gain and an increase in the number of breeding cycles required to generate a final product. In contrast, MAS offers the potential to assemble target traits in the same genotype more precisely, with fewer unintentional losses in fewer selection cycles (Xu and Crouch, 2008). In this way, target traits can be selected indirectly using molecular markers that are closely linked to underlying genes or that have been developed from the actual gene sequence. Hence drought has been a trait difficult to manage through the conventional phenotypic selection and is one of the most ideal traits for improvement through MAS (Collins et al., 2008).

In the last few decades, new DNA molecular markers based on the PCR technique, such as random amplified polymorphic DNA (RAPD) and inter simple sequence repeats (ISSRs) have become excellent tools for rice plant breeders. One of the most adequate marker systems is RAPD amplification. This technique can give fast results, but has some limitations such as: dependence on the genetic background, low reproducibility and level of polymorphism obtained (Lima-Brito et al., 2006). In contrast to RAPD amplification, the ISSR markers are more feasible, reproducible and distribution of ISSRs in the eukaryotic genome makes them highly informative. They are also highly polymorphic and their use is cost effective, requiring no prior information of the sequence.

ISSR markers also used to study genetic diversity and phylogenetic relationships, for gene mapping, gene tagging in molecular assisted selection and DNA finger printing (Carvalho et al., 2005). The recent, identification of major QTLs governing grain yield under drought has made possible to use of MAS for improving drought resistance. Progress in mapping QTLs for secondary traits associated with drought resistance has been extensively reviewed. But, MAS for such QTLs has not been successfully used to improve yield under drought stress in rice (Venuprasad et al., 2009).

However., Bernier et al. (2007) reported a QTL on chromosome 12 in a Vandana and Kumar et al. (2007) reported a major QTL for grain yield under lowland drought stress in a CT9993/IR62266 population on chromosome 1 explaining 32\% of the genetic variance for the trait over two years. With the prevalence of a few mega-varieties being cultivated on millions of hectares in major drought-prone areas in eastern India and northeastern Thailand, the two major droughtprone areas in the world, identifying major QTLs for grain yield in the background of improved mega varieties and introgressing the identified QTLs in the same background to improve the drought resistance of current mega-varieties have been suggested as an alternative approach.

Recently, Venuprasad et al. (2009) using this approach and bulk segregant analysis, identified two major QTLs located on chromosomes 2 and 3 for grain yield under lowland drought and one QTL on chromosome 6 for yield potential and tolerance of aerobic soil conditions. These QTLs have been identified in the background of drought-susceptible variety Swarna, grown on millions of hectares in India, Nepal, and Bangladesh and they are being introgressed using MAB to improve the drought resistance of Swarna.

In addition, SUB1, a major QTL for submergence tolerance has been introgressed into Swarna, Sambha Mahsuri, IR64, and BR11 mega-varieties (Septiningsih et al., 2009). In the case of drought QTLs related to grain yield under drought stress have been reported on numerous occasions in rice, but there have been no reports of the successful use of such QTLs in MAS. The lack of repeatability of QTL effects across different populations (QTL x genetic background interactions) and across environments (QTL $\mathrm{x}$ environment interactions) are the two factors limiting the use of QTLs for MAS (Bernier et al., 2008).

\subsection{Genetic Engineering Approach}

Plant breeding strategy for drought tolerance is not much successful due to reproductive barrier and also as it involves the risk of other undesirable traits transfer. So to avoid this 
problem, genetic engineering strategy is more preferred since it only deals with the specific gene(s) of interest to be transferred.

The development of transgenic rice with improved drought resistance can be achieved through two complementary approaches:

* Mobilizing genes for resistance within rice germplasm using high-throughput QTL analysis and allele mining leading to map-based cloning of rice alleles affecting growth and yield under drought stress, and

Exploiting in rice sequences demonstrated to enhance drought resistance in other species.

Rice germplasm has extensive unexploited variation for drought resistance. IRRI research has shown that variation for the trait can be strongly influenced by alleles of a relatively small set of QTLs with large effects. Transgenic rice plants have also been produced to over-express transcription factors involved in the regulation of stress-inducible genes such as CBF/DREB1, DREB2, RD29B, RD22 and ICE1((Navabi et al., 2009). Candidate genes for drought include DREB2a, ERF3, sucrose synthase, actin depolymerizing factor and trehalose-6-phosphate phosphatase. Most of the CBF/DREB1 target genes contain the DR motif with a conserved $(\mathrm{A} / \mathrm{G})$ CCGACNT sequence in their promoter regions. The target gene products of these proteins are consequently involved in establishing stress tolerance. The DREB2 genes are induced by dehydration stress and may activate other genes involved in drought stress tolerance (Ito et al., 2006).

Madabula et al. (2016) were evaluated 4 genes related to auxin response and root modifications (OsGNOM1/CRL4, OsIAA1, OsCAND1 and OsRAA1).The expression of these genes were analyzed in stressed rice using public available microarray data and then through real-time quantitative polymerase chain reaction(RT-qPCR). Transcription factors (TFs) which can interact with cis-regulatory sequences and regulate a series of related genes expression were critical components of the abiotic stress signal transduction pathway.

Genes and their control sequences previously determined to improve drought resistance in other species had also a potential value in rice and can be evaluated using high-throughput transformation and phenol typing systems. Sequences licensed from both the public and commercial sectors and already proven to enhance performance under drought stress can be evaluated using this approach to assess the effect of these sequences on a range of drought related traits and move the most promising ones into widely grown, high quality rice megavarieties(Hervé and Serraj, 2009). Stress-responsive rice SNAC genes such as SNAC1, OsNAC6/SNAC2 and OsNAC5 improve drought tolerance when over expressed. As indicated in table below, many TFs have been used to produce transgenic rice lines with either constitutive or inducible promoters (Ravikumar et al., 2014).

Table1. Genetic engineering of transcrpiption factors for enhancing drought tolerance in rice

\begin{tabular}{|c|c|c|c|c|c|}
\hline Gene/protein & Name & Source & | Promoter & I phenotype & Reference \\
\hline $\begin{array}{l}\text { NAC fat } \\
\text { SNAC1 }\end{array}$ & Stress & Oryza sativa & CaMv35s & $\begin{array}{l}\text { Drought and } \\
\text { salinity tolerance }\end{array}$ & ${ }_{2006}^{\mathrm{Hu}}$ et al. \\
\hline NACG/SNAC2 & $\begin{array}{l}\text { Stress } \\
\text { responsive } \\
\text { NAC2 }\end{array}$ & Oryza sativa & $\begin{array}{l}\text { OSNAC6, } \\
\text { LIP9 }\end{array}$ & $\begin{array}{l}\text { Tolerance to } \\
\text { cold, salt stress }\end{array}$ & $\begin{array}{l}\text { Nakashima et } \\
\text { al., } 2007\end{array}$ \\
\hline NACO4S & $\begin{array}{l}\text { NACO4S } \\
\text { transcription } \\
\text { factor }\end{array}$ & Oryza sativa & CaMv35s & $\begin{array}{l}\text { Drought and salt } \\
\text { stress }\end{array}$ & $\begin{array}{l}\text { Zheng ef al. } \\
2009\end{array}$ \\
\hline NAC1O & $\begin{array}{l}\text { NAC10 } \\
\text { transcription } \\
\text { factor }\end{array}$ & Oryza sativa & GOS2, RCe3 & $\begin{array}{l}\text { Tolerance to } \\
\text { drought and low } \\
\text { temperature }\end{array}$ & $\begin{array}{l}\text { Jeong et al. } \\
2010\end{array}$ \\
\hline OSNAC6 & & Oryza sativa & CaMv35S & $\begin{array}{l}\text { Drought } \\
\text { tolerance }\end{array}$ & \begin{tabular}{|l} 
Rachmat \\
al., 2014
\end{tabular} et \\
\hline $\begin{array}{l}\text { Basic leucine zi } \\
\mathrm{ABF}^{3}\end{array}$ & $\begin{array}{l}\text { per transeription } \\
\text { responsive } \\
\text { responent binding } \\
\text { elementent bector }\end{array}$ & $\begin{array}{l}\text { factor } \\
\text { Arabidopsis } \\
\text { thaliana }\end{array}$ & Ubiquitin & $\begin{array}{l}\text { Drought } \\
\text { tolerance }\end{array}$ & $\operatorname{logs}_{200}^{\text {Oh }}$ al. \\
\hline BZ1P23 & \begin{tabular}{|l|} 
Protein/tactor3 \\
Basie leucine \\
zipper 23
\end{tabular} & Oryza sativa & Ubiquitin & $\begin{array}{l}\text { ABA sensitive } \\
\text { salinity } \\
\text { dirought tolerandec }\end{array}$ & $\begin{array}{l}\text { Xiang ef al. } \\
2008\end{array}$ \\
\hline BZIP46 & \begin{tabular}{|l|} 
Basic \\
zipper 46
\end{tabular} & Oryza sariva & Ubiquitin & $\begin{array}{l}\text { Drought streand } \\
\text { osmotic stresses } \\
\text { tolerance }\end{array}$ & $\begin{array}{l}\text { Tang ef al. } \\
2012 \text {. }\end{array}$ \\
\hline bZ1P72 & $\begin{array}{l}\text { Basic } 72^{\text {leucine }} \\
\text { zipper }\end{array}$ & Oryza sativa & CaMv3ss & 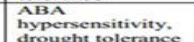 & $\underset{20008}{\operatorname{Lu}}$ ef al. \\
\hline HD-Zip & $\begin{array}{l}\text { Homeodormain } \\
\text { leucine zipper }\end{array}$ & Oryza sativa & CaMv3ss & $\begin{array}{l}\text { Plant } \\
\text { development and } \\
\text { drought stress } \\
\text { adaptation stress }\end{array}$ & $\begin{array}{l}\text { Agalou ef al.. } \\
\text { zoos }\end{array}$ \\
\hline $\begin{array}{l}\text { MYB-Type trat } \\
\text { MYB2 }\end{array}$ & $\begin{array}{l}\text { Seription factor } \\
\text { Mrans-Type } \\
\text { transeription } \\
\text { factor }\end{array}$ & Oryza sativa & Ubiquitin & \begin{tabular}{|l|l|} 
Salt, cold and \\
dehydration \\
tolerance
\end{tabular} & $\begin{array}{l}\text { Yang } \\
\text { al.2012 }\end{array}$ \\
\hline $\begin{array}{l}\text { Zine finger tra } \\
\text { ZFP2S2 }\end{array}$ & $\begin{array}{l}\text { eription factors } \\
\text { C-repeat DRE } \\
\text { element binding } \\
\text { factors bing }\end{array}$ & Oryza sativa & CaMv3ss & $\begin{array}{l}\text { Tolerance to salt } \\
\text { and } \\
\text { stresses drought }\end{array}$ & $\mathrm{Xu}_{1996}$ et al. \\
\hline ZFP24S & $\begin{array}{l}\text { Zine } \begin{array}{l}\text { finger } \\
\text { protein } 245\end{array} \\
\end{array}$ & Oryza sativa & CaMv3ss & 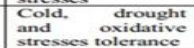 & $\begin{array}{l}\text { Huang of al. } \\
2009\end{array}$ \\
\hline
\end{tabular}




\begin{tabular}{|c|c|c|c|c|c|}
\hline DREB $1 \mathrm{~A} / \mathrm{CB} 3$ & $\begin{array}{l}\text { C-repeat/DRE } \\
\text { element binding } \\
\text { factors }\end{array}$ & $\begin{array}{l}\text { Arabidopsis } \\
\text { thaliana }\end{array}$ & Ubiquitin & $\begin{array}{l}\text { Drought, } \begin{array}{r}\text { Salt, } \\
\text { and freezing } \\
\text { tolerance }\end{array} \\
\end{array}$ & $\begin{array}{l}\text { Oh et al., } \\
2005\end{array}$ \\
\hline HARDY & $\begin{array}{l}\text { AP2/ERF like } \\
\text { transcription } \\
\text { factor }\end{array}$ & $\begin{array}{l}\text { Arabidopsis } \\
\text { thaliana }\end{array}$ & CaMV35S & $\begin{array}{l}\text { Drought, } \begin{array}{r}\text { Salt, } \\
\text { and freezing } \\
\text { tolerance }\end{array} \\
\end{array}$ & $\begin{array}{l}\text { Karaba et al., } \\
2007\end{array}$ \\
\hline TERF1 & $\begin{array}{l}\text { Tomato } \\
\text { ethylene } \\
\text { responsive } \\
\text { factor } \\
\end{array}$ & \begin{tabular}{|l|}
$\begin{array}{l}\text { Lycopersium } \\
\text { esculatum }\end{array}$ \\
\end{tabular} & CaMV35S & $\begin{array}{l}\text { Drought and } \\
\text { salinity tolerance }\end{array}$ & $\begin{array}{lll}\text { Gao } & \text { et } & \text { al. } \\
2008 & & \end{array}$ \\
\hline DREB1F & $\begin{array}{|ll|}\begin{array}{l}\text { DREB } \\
\text { protein }\end{array} & \text { class } 1 \\
\end{array}$ & Oryza sativa & CaMV35S & $\begin{array}{l}\text { Salt, drought and } \\
\text { low temperature } \\
\text { tolerance }\end{array}$ & $\begin{array}{l}\text { Wang et al., } \\
2008\end{array}$ \\
\hline $\begin{array}{l}\text { OSDREB1G, } \\
\text { OsDREB2B }\end{array}$ & \begin{tabular}{|l|} 
DREB class 1 \\
and 2 protein
\end{tabular} & Oryza sativa & CaMV35S & $\begin{array}{l}\text { Water deficit } \\
\text { stress tolerance }\end{array}$ & $\begin{array}{l}\text { Chen et al., } \\
2008\end{array}$ \\
\hline JERF3 & $\begin{array}{l}\text { Ethylene } \\
\text { response factor }\end{array}$ & & CaMV35S & $\begin{array}{lr}\begin{array}{lr}\text { drought } \\
\text { osmotic }\end{array} & \text { and } \\
\text { tolerance } & \text { stress } \\
\end{array}$ & $\begin{array}{l}\text { Zhang et al., } \\
2010\end{array}$ \\
\hline AP37 & \begin{tabular}{|l|} 
AP2/ERF \\
domain \\
containing \\
transcription \\
factors \\
\end{tabular} & Oryza sativa & OsCe1 & $\begin{array}{l}\text { Drought and high } \\
\text { salinity tolerance }\end{array}$ & $\begin{array}{l}\text { Oh et al., } \\
2009\end{array}$ \\
\hline TSRF 1 & \begin{tabular}{|l|} 
Tomato \\
ethylene \\
responsive \\
factors \\
\end{tabular} & Oryza sativa & CaMV35S & $\begin{array}{|ll|}\begin{array}{l}\text { Drought } \\
\text { tolerance }\end{array} & \text { stress } \\
\end{array}$ & $\begin{array}{l}\text { Quan } \\
2010\end{array}$ \\
\hline ARAG1 & $\begin{array}{l}\text { ABA- } \\
\text { responsive } \\
\text { DREB gene }\end{array}$ & Oryza sativa & CaMV35S & $\begin{array}{l}\text { Seed germination } \\
\text { and drought } \\
\text { tolerance }\end{array}$ & $\begin{array}{l}\text { Zhao et al., } \\
2010\end{array}$ \\
\hline SUB1A & $\begin{array}{l}\text { ERF } \\
\text { transcription } \\
\text { factor }\end{array}$ & Oryza sativa & Ubiquitin & $\begin{array}{lr}\begin{array}{l}\text { Drought } \\
\text { oxidative } \\
\text { tolerance }\end{array} & \begin{array}{r}\text { and } \\
\text { stress }\end{array} \\
\end{array}$ & $\begin{array}{l}\text { Fukao et al., } \\
2011\end{array}$ \\
\hline DERF1 & $\begin{array}{l}\text { Drought and } \\
\text { ethylene- } \\
\text { responsive } \\
\text { factor }\end{array}$ & Oryza sativa & $\begin{array}{l}\text { CaMV35S, } \\
\text { Actin 1 }\end{array}$ & drought sensitive & $\begin{array}{l}\text { Wan et al., } \\
2011\end{array}$ \\
\hline OSWR1 & $\begin{array}{l}\text { Rice wax } \\
\text { synthesis } \\
\text { regulatory gene }\end{array}$ & Oryza sativa & $\begin{array}{l}\text { CaMV35S, } \\
\text { Actin 1 }\end{array}$ & $\begin{array}{l}\text { Drought } \\
\text { tolerance }\end{array}$ & $\begin{array}{l}\text { Wang et al., } \\
2011\end{array}$ \\
\hline DREB2A & $\begin{array}{l}\text { DREB class2 } \\
\text { protein }\end{array}$ & Oryza sativa & 4XABRC & $\begin{array}{l}\text { Drought and salt } \\
\text { tolerance }\end{array}$ & $\begin{array}{l}\text { Cui } \\
2011\end{array}$ et al., \\
\hline DREB2A & $\begin{array}{l}\text { DREB class2 } \\
\text { protein }\end{array}$ & Oryza sativa & RD29 & $\begin{array}{l}\text { Dehydration and } \\
\text { salt } \\
\text { tolerance stress }\end{array}$ & $\begin{array}{l}\text { Mallikarjuna } \\
\text { et al., } 2011\end{array}$ \\
\hline AtDREB1A & & Oryza sativa & CaMV35S & $\begin{array}{l}\text { Drought } \\
\text { tolerance }\end{array}$ & $\begin{array}{l}\text { Hussain et al., } \\
2014\end{array}$ \\
\hline
\end{tabular}

Source: (Ravikumar et al., 2014).

IRRI has also undertaken research on multigene and targeted gene delivery methods which could be used to deliver transgenes at chosen positions in the genome to minimize position effects associated with transgene expression. The drought resistance genes found by these approaches at IRRI will be international public goods (Hervé and Serraj, 2009).
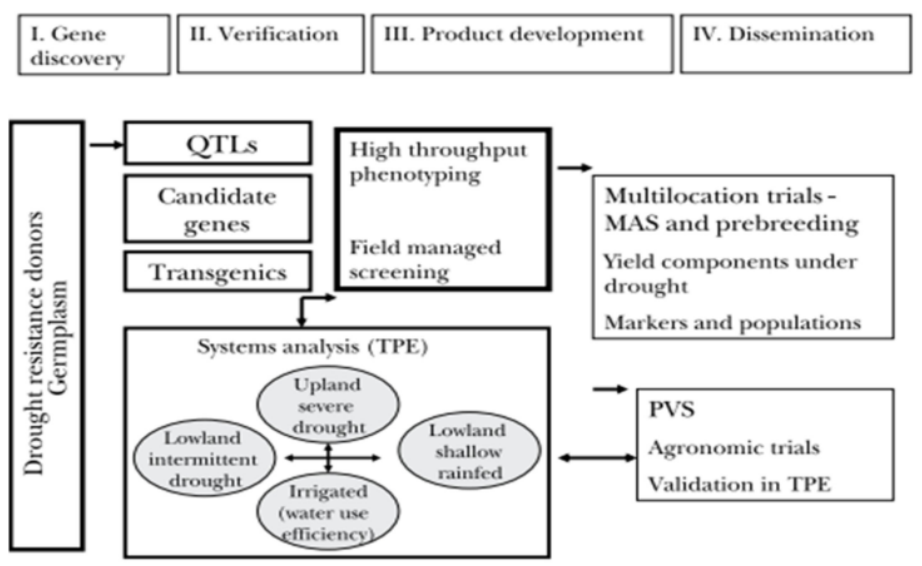

Fig5. Framework of an integrated strategy for genetic enhancement of drought resistance in rice

Source: (Rachid et al., 2011)

The strategy involves the identification of drought resistance donors, major QTLs, candidate genes and transgenics, testing in high throughput phenotyping plate form and field managed stress screening and validation in the target population of environment with system analysis. The advanced breeding lines and products are further tested in large scale multiplication trials in collaboration with NARS partners and in farmers' fields using participatory varietal selection (PVS) and agronomic management trials.

\section{Progress of Rice Production and Research in Ethiopia}

Rice is among the most important cereal crops grown in different parts of Ethiopia as food crop (NRRDSE, 2009). The discovery of wild rice at Fogera plain was the bases for rice introduction activity in Ethiopia (Getachew, 2000). Rice is a recent introduction in Ethiopia; however, its 
importance is being well recognized in the country as the area coverage of 18527 ha and total production of 42825 tons in 2006 has increased into 48,418.09 ha and 1,360,007.26 tons in 2017(Asefa, 2011; CSA, 2017). In Ethiopia, rice ecosystems have been classified as rain-fed low land, upland and irrigated low land rice ecosystems (MoARD, 2009). Ethiopian Institute of Agricultural Research (EIAR) has treated rice as one of the nationally coordinated research projects. Since the crop is a recent introduction in the country, its research status is at the infant stage. However, thirty five improved rice varieties with different characteristics have been released and registered.

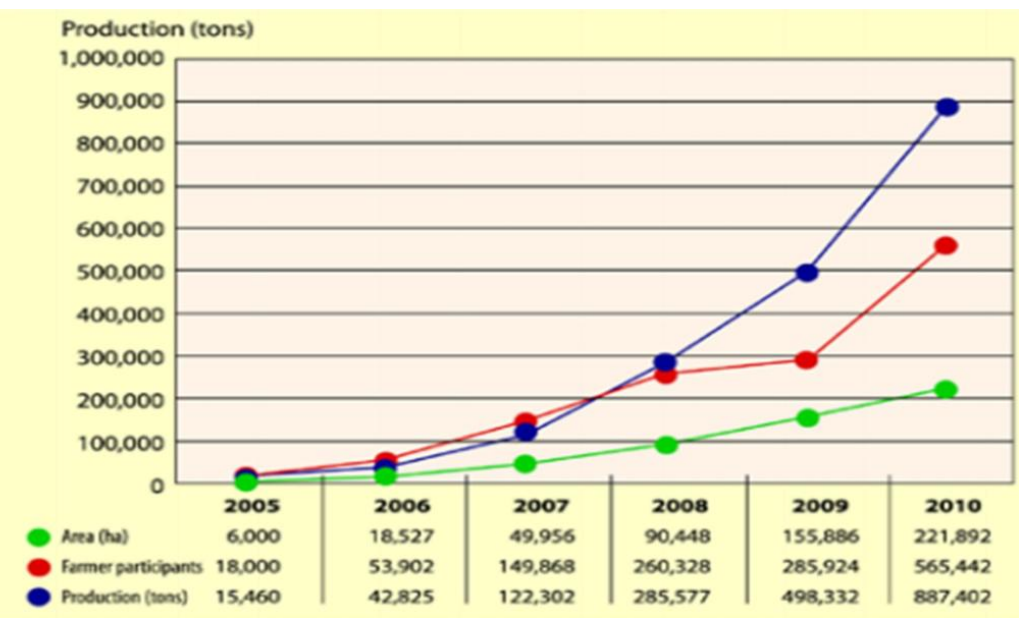

Fig6. Rice production in Ethiopia 2005-2010

Source: (MOARD, 2010)

The Ethiopian government has already formulated its national rice development strategy and has made partnership arrangements with local and international stake holders (Mulugeta, 1999). Generally, the rice cultivation has started in Afar, Amhara, Oromiya, Benshagul Gumez, Gambella, Somali, Southern nations and nationalities and Peoples Region(SNNPR) and Tigray regions in the country and has been progressing steadily (MoARD, 2010; Kebebew et al; 2011).

Rice breeding activity in the country has two major components (enhancing germplasm variability and variety development) for different agro-ecologies. As the success of plant breeding research depends on the availability of genetic variation. Thus, rice is not indigenous to Ethiopia; the source of germplasm is through introduction. Introduction and evaluation of rice germplasm for biotic (diseases, insect pests, weeds) and abiotic (cold and salinity) stresses are started. However, not yet activities started for drought tolerance rice in Ethiopia

\section{CONCLUSION}

Rice is the staple food for more than one half of the world's population and is grown widely in 114 countries across the world. However, rice is a semiaquatic species highly susceptible to drought. Global warming, unpredictable rainfall patterns and climate change would cause more severe stress situations in the rain-fed agro-ecosystems in future. In most upland rice environments, droughts were unpredictable and did not occur every year. Farmers were not willing to sacrifice yield loss in drought years. Plant breeders must therefore select varieties capable of producing relatively high yields in both favorable and unfavorable years.

The three major breeding approaches next to preliminary activities for drought tolerance varietal development are conventional breeding, marker assisted selection and genetic engineering. Modern breeding approaches have a greater advantage than conventional for drought tolerance.

Because of that markers

- Identify a desirable gene, even in the absence of a visible trait

- Breeding result is more precise and efficient

- Identify undesirable genes that can be eliminated in future generations

Among DNA molecular markers, based on the PCR technique, such as random amplified polymorphic DNA (RAPD) and inter simple sequence repeats (ISSRs) have become excellent 
tools for rice breeders. ISSR markers are preferable than RAPD due to more feasible and reproducible and the distribution is highly informative, highly polymorphic, their use is cost effective and requiring no prior information of the sequence. But, not yet reported for the successful use of QTLs in MAS. Transgenic rice varieties also need to be evaluated under drought environment to validate their actual potential. Ethiopia has wide agro-ecologies including agricultural drought prone environments. However, not yet identify rice genotypes for drought tolerance. So, it needs a great effort to screen and develop drought tolerant high yielding varieties in the country. Beside, these are good opportunities for breeders who have a chance to do on it.

\section{REFERENCES}

[1] African biotechnology stakeholder's forum (ABSF). 2010. Success Stories in Crop Improvement in Africa: The Case of Rice in Sub-Saharan Africa

[2] Beakal Tadesse, Hussein Mohammed and Kebede Abegaz.2016. Physical characteristics and nutritional quality of salt

[3] Bernier J., Atlin G.N., Serraj R., Kumar A. \& Spaner D. 2008. Breeding upland rice for drought resistance. J. Sci. Food Agric. 88: 927-939.

[4] Bernier J., Kumar A., Venuprasad R., Spaner D \& Atlin G.2007. Large- effect QTL for grain yield under reproductive-stage drought stress in upland rice. Crop Sci 47:507-518

[5] Calpe C. 2006. Rice international commodity profile. Food and Agriculture Organization of the United Nations. Markets and Trade Division .pp 23

[6] Chakravarthi B.K. \& Naravaneni R. 2006. SSR marker based DNA fingerprinting and diversity study in rice (Oryza sativa. L). African Journal of Biotechnology. 5(9):12-15

[7] Cooper M., Fukai S. \& Wade L. 1999. How can breeding contribute to more productive and sustainable rainfed lowland rice systems? Field Crops Res. 64: 199-209.

[8] Courtois B., McLaren G., Sinha PK., Yadav R.\& Shen L.2000. Mapping QTL associated with drought avoidance in upland rice. Mol Breed 6:55-66

[9] Farooq M., Kobayashi N., Ito O., Wahid A. \& Serraj R. 2009. Broader leaves result in better performance of indica rice under drought stress. J. Plant Physiol.167: 1066-1075.

[10] Fischer KS., Lafitte R., Fukai S., Atlin G. \& Hardy B. 2003. Breeding rice for drought-prone environments. Los Baños (Philippines): International Rice Research Institute. 98p.

[11] Food and Agriculture Organization of the United Nations (FAO).2013.Cereal Supply and demand Brief(http:// www.fao.org/worldfoodsituation / wfs-home/csdb/en/)

[12] Gall H., Philippe F., Domon J., Gillet F., Pelloux J. \& Rayon C.2015. Cell wall metabolism in response to abiotic stress. Plants, 4: 112-166.

[13] Hirasawa T.1999. Physiological characterization of rice plant for tolerance of water deficit, in Genetic Improvement of Rice for Water-Limited Environments. IRRI, Los Banos, Philippines, pp. 89-98

[14] Jaleel P., Manivannan A., Wahid M., Farooq R. \& Panneerselvam R. 2009. Drought stress in plants: a review on morphological characteristics and pigments composition. Int. J. Agric.Biol., 11: 100-105

[15] Jongdee B, Pantuwan G, Fukai S. \& Fischer K. 2006. Improving drought tolerance in rain-fed lowland rice: an example from Thailand. Agric Water Manage 80:225-240

[16] Jongdee B., Fukai S. \& Cooper M. 2002. Leaf water potential and osmotic adjustment as physiological traits to improve drought tolerance in rice. Field Crops Res 76:153-163

[17] Kebebew Assefa, Dawit Alemu, Kiyoshi Shiratori \&Abebe Kirub.2011. Challenges and opportunities of rice in Ethiopian. Agricultural Development JICA FRG II project

[18] Khirod K., Amit K. \& Sneh L. 2013. Taming drought stress in rice through genetic engineering of transcription factors and protein kinases.

[19] Khush GS .1997. Origin, dispersal, cultivation and variation of rice. Plant Mol Biol 35:25-34

[20] Kumar R., Venuprasad R. \& Atlin G.N. 2007. Genetic analysis of rainfed lowland rice drought tolerance under naturally-occurring stress in eastern India: heritability and QTL effects. Field Crops Res. 103: 42-52.

[21] Lafitte HR, Ismail A. \& Bennet J. 2004. Abiotic stress tolerance in rice for Asia: progress and the future, in New Directions for a Diverse Planet: Proceedings of the 4th International Crop Science Congress

[22] Laure G., Jean-Louis P. \& Bernard B. 2010. What are the prospects for genetic improvement in droughttolerant crop plants

[23] Liu JK, Liao DQ, Oane R., Estenor L. \& Yang XE.2006. Genetic variation in the sensitivity of anther dehiscence to drought stress in rice. Field Crops Res 97:87-100 
[24] Luz V. K., Silveira S. F., Fonseca G. M., Baretta D. \& Oliveira A. C. D. 2016. Identification of variability for agronomic ally important traits in rice mutant families. Bragantia.75 (1):41-50.

[25] Medrano H, Escalona JM, Bota J, Gulias J. \& Flexas J. 2002. Regulation of photosynthesis of C3 plants in response to progressive drought: stomatal conductance as a reference parameter. Ann Bot 89:895-905

[26] MoARD (Ministry of Agriculture and Rural Development). 2010. National rice research and development strategy.Ministry of Agriculture and Rural Development, the Federal Democratic Republic of Ethiopia. Addis Ababa, Ethiopia. 48p

[27] Mohan JS., Brar DS. \& Ahloowalia BS .2002. QTLs for root growth and drought resistance in rice, in Molecular Techniques in Crop Improvement. pp. 563-584

[28] Mohanty S., smann Nelson A., Moya P. \&Jagadish K. 2013. Rice and climate change: significance for food security and vulnerability.

[29] Navabi A., Mather D.E., Bernier J., Spaner D.M. \&Atlin G.N. 2009. QTL detection with bidirectional and unidirectional selective genotyping: marker-based and trait-based analyses. Theor. Appl. Genet. 118: 347358

[30] Ndjiondjop M., Semagn K., Cissoko M., Tsunematsu H. \& Jones M. 2006. Genetic relationship among rice varieties based on expressed sequence tags and microsatellite markers.Asian J Plant Sci5:429-437

[31] Pandey S., Behura D., Vilano R. \& Naik D. 2000. Economic cost of drought and farmers' coping mechanisms: a study of rain-fed rice systems in Eastern India, in Discussion Paper Series. International Rice Research Institute, Makati City, Philippines, 35p

[32] Pantuwan G., Fukai S., Cooper M., Rajatasereekul S. \& Otoole JC. 2002. Yield response of rice (Oryza sativa L.) genotypes to drought under rainfed lowlands. Field Crops Res 73:169-180

[33] Passioura J.2006. Increasing crop productivity when water is scarce: from breeding to field management. Agric Water Manage 80:176-196

[34] Rachid S, Kenneth L., Inez S., Ajay Kohli, Gary A. \& Arvind K.2011.Drought Resistance Improvement in Rice: An Integrated Genetic and Resource Management Strategy, Plant Production Science, 14:1, 1-14

[35] Septiningsih E.M., Sanchez D.L., Ismail A.M. \& Mackill D.J.2009. Development of submergencetolerant rice cultivars: the Sub1locus and beyond. Ann. Bot. 103: 151-160

[36] Venuprasad R., Dalid C., Espiritu M., Amante M., Atlin G. \& Kumar A. 2009. Identification and characterization of large-effect quantitative trait loci (QTL) for grain yield under lowland drought stress in rice using bulk-segregant analysis (BSA). Theor. Appl. Genet. 120: 177-190.

[37] Venuprasad R., Lafitte HR. \& Atlin GN. 2007. Response to direct selection for grain yield under drought stress in rice. Crop Sci 47:285-293

[38] Wade L., McLaren C.G., Quintana L., Siopongco J. \& Sarkarung S. 1999. Genotype by environment interactions across diverse rain-fed lowland rice environment. Field Crops Res. 64: 35-50

[39] Wang C, Liu X, Peng S, Xu Q, Yuan X. 2014. Development of novel microsatellite markers for the BBCC Oryza genome (Poaceae) using high-throughput sequencing technology. PloS one 9: p.e91826.

[40] Wassmann R., Jagadish V.K., Sumfl eth K., Pathak H. \& Heuer S. 2009. Regional vulnerability of climate change impacts on Asian rice production and scope for adaptation. Adv. Agron. 102: 91- 133.

[41] Yambao E.B., Ingram K.T. \& Real G .1999. Root xylem influence on the water relations and drought resistance of rice. Exp Bot 43:925-932

[42] Zibaee A. 2013. Rice importance and Future. Department of Plant Protection, Faculty of Agricultural Sciences, University of Guilan, Iran. Joural of Rice Research.1:2

Citation: Dejen Bekis, "Review on Rice Improvement for Drought Tolerance" International Journal of Research Studies in Agricultural Sciences (IJRSAS), 2019; 5(6), pp. 9-21, http://dx.doi.org/10.20431/24546224.0506002

Copyright: (C) 2019 Authors. This is an open-access article distributed under the terms of the Creative Commons Attribution License, which permits unrestricted use, distribution, and reproduction in any medium, provided the original author and source are credited. 